\title{
ADLİ MUHASEBEDE UZMAN TANIKLIK MESLEĞİ: MUHASEBE MESLEK MENSUPLARI ÜZERİNE BİR ARAŞTIRMA ${ }^{1}$
}

\author{
Doç. Dr. Fikret ÇANKAYA* \\ Doç. Dr. Engin DíNÇ** \\ Yurdagül ÇOBAN***
}

\begin{abstract}
ÖZ
Adalet sisteminin ayrılmaz bir parçası olan bilirkişilik uygulamasının ciddi sorunları bulunduğuna yönelik pek çok çalışma mevcuttur. Adalet sistemindeki bu soruna çözüm getirebileceği düşünülen müesseselerden biri de uzman tanıklıktır. Uzman tanıklı̆̆ın, adalet sisteminin sorunlarına çare olup olmayacağını ortaya koymak bu çalışmanın ana amacıdır. Bir diğer amaç ise adalet uygulayıcılarının uzman tanıklara ihtiyacı olup olmadığını, muhasebe meslek mensuplarının buna uygun olup olmadikların tespit etmek ve muhasebe meslek mensuplart ile adalet uygulayıcılarinın düşüncelerini ortaya koymaktır. Bu amaçla, hazırlanan iki farklı anket 495 muhasebe meslek mensubu ve 60 yargı mensubu üzerinde uygulanmıştır. Araştırma sonucunda, ülkemizde sertifikalı bilirkişi olarak görev yapacak uzman tanıklara ihtiyaç duyulduğu ve muhasebe meslek mensuplarının şu an için gerekli uzman tanıklık yeterliliğine sahip olmadĭ̆ı tespiti yapılmıştır.
\end{abstract}

Anahtar sözcükler: Uzman Tanıklık, Adli Muhasebe, Dava Destek Danışmanlığı.

Jel Sinıflandirması: M40, M41, M42, M49

\section{EXPERT WITNESSING PROFESSION IN FORENSIC ACCOUNTING: A RESEARCH ON MEMBERS OF ACCOUNTING PROFESSION}

\begin{abstract}
A considerable amount of literature has been published on the fact that court expertise practice, which is an indispensable part of the justice system, has serious problems. One of the solutions that can be suggested to eradicate this problem of the justice system is expert witnessing. This study mainly aims at investigating whether expert witnessing can constitute a solution to the problems of the justice system. The study also seeks to give an account of the fact whether the justice implementers need expert witnesses and to diagnose whether the accounting professional groups are suitable for this as well as to reveal the opinions of both the accounting professional groups and justice implementers about the issue. Thus, two different questionnaires which were distributed to 495 participants of

\footnotetext{
${ }^{1}$ Bu çalışma Karadeniz Teknik Üniversitesi, Sosyal Bilimler Enstitüsü’nce kabul edilen “Adli Muhasebede Uzman Tanıklık Mesleği: Muhasebe Meslek Mensupları Üzerine Bir Araştırma” adlı yüksek lisans tezinden türetilmiştir.

* Karedeniz Teknik Üniversitesi, İ̈BF, İşletme Bölümü cankayaf@ yahoo.com

** Karedeniz Teknik Üniversitesi, İ̈BF, İşletme Bölümü, edinc66@gmail.com

*** Sosyal Güvenlik Kurumu Başkanlığı, Sosyal Güvenlik Denetmen Yardımcısı, yurdagulcoban86@hotmail.com
} 
accountancy profession and 60 judges were used respectively. One of the more significant findings to emerge from this study is that expert witnesses who will work as certified experts are needed in Turkey and it has been diagnosed that the current accounting professionals are not qualified for expert witnessing.

Key Words: Expert Witnessing, Forensic Accounting, Litigation Support Consulting

Jel Classification: M40, M41, M42, M49

\section{GIRIŞ}

Günümüz Türkiye'sinde adalet sisteminin önemli bir parçası olan bilirkişilik müessesesinin birçok sorun yaşadığı ve sistemde yeni bir düzenlemeye gidilmesi gerektiği birçok araştırmacı ve uygulayıcı tarafindan kabul edilmektedir (Akyel, 2009: 205). Adalet siteminde yaşanan bu sorunlar; hukuki konularda bile bilirkişiye gidilmesi, bilirkişilerin hakimin yerine geçerek onun yetkisini kullanmas1 (Seviğ, 2002: 1; Bakırc1, 2003: 1), konusunda uzman olmayan, eş, dost tavsiyesi veya hatır, gönül ilişkileri çerçevesinde seçilen, davanın çözümüne yönelik hukuki ve teknik inceleme becerisi olmayan kişilerin bilirkişi olarak görevlendirilmesi (Bakırc1, 2003: 1), bilirkişilik hizmetinin ek gelir sağlanacak ek iş olarak görülmesi (Çelikli, 2006b: 1), bilirkişinin tarafsız olmaması, bilirkişinin dürüst olmaması, bilirkişinin ehil ve uzman olmaması, bilirkişi tarafından uyuşmazlığın tam olarak anlaşılamaması, taraflar ile ilişki içerisinde bulunulması, yeterli araştırma ve inceleme yapılmaması, bilirkişi raporunun süresi içerisinde verilmemesi (Çınar, 2009: 121-148) şeklinde siralanabilmektedir.

Bilirkişilik sisteminde yaşanan bu sorunlara çözüm arayan araştırmacı ve uygulayıcılar, adli muhasebe adı altında bir dizi çalışmaya imza atmışlardır. Araştırmacılar arasında, adalet sistemindeki sorunlarla baş edebilmenin, adli muhasebe anlayışının yerleşmesi ile mümkün olacağına yönelik yaygın bir görüş mevcuttur. Adli muhasebe sisteminin en önemli ayağı ise uzman tanıklık müessesesidir. Bu nedenle, çalışmada, önce uzman tanıklık mesleği ele alınmış, sonra bu konudaki literatür hakkında bilgi verilmiş, daha sonra yapılan araştırma sonucunda mevcut adalet uygulayıcılarının uzman tanıklık mesleğinin mevcut sorunlara çözüm olup olamayacağı konusunda ne düşündükleri ve bu mesleği icra etmesi muhtemel olan muhasebe meslek mensuplarının bu konuda yeterli olup olmadıkları hususunda meslek mensupları ile yargı mensuplarının düşüncelerinin ne olduğu sorusuna cevap aranmıştır.

\section{KAVRAMSAL ÇERÇEVE}

\subsection{Adli Muhasebe ve Adli Muhasebecilik}

Adli Muhasebe mesleği, 1980'li yıllardan itibaren ağıllıklı olarak başta ABD olmak üzere gelişmiş ülkelerde önemli bir meslek olarak kabul görmüş ve gelişmeye başlamıştır. Meslek orijinal 
ismi ile "Forensic Accounting" olarak anılmaktadır (Bozkurt, 2000: 56). Adli muhasebe; muhasebe, denetim ve araştırma becerilerinden oluşan bütünleşmiş bir uzmanlık alanıdır. Bu anlamda adli muhasebeciler, adli sorunlarda dava mahkemeye intikal etmeden önce veya dava aşamasında, anlaşmazlığın çözüme kavuşturulması için gerekli noktaları belirleyecek bir hesap analizi ve uzman görüşü sağlar (Crumbley, 1995: 23). Adli muhasebe, adli yargı kurumlarının kararlarına yardımcı olmak üzere finans, hukuk ve ticaret alanındaki işlemlere ilişkin kapsamlı bir bilgi seviyesine ve bu bilgi seviyesinin uzmanlarca kullanılmasına ilişkin bir anlayıştır (Karacan, 2012: 107). Adli muhasebe; hukuk ve muhasebe uzmanlık alanlarının birleşiminden oluştuğu kadar kendisine denetim uygulamalarını, soruşturma yöntemlerini, suç bilimini, bilişim teknolojilerini, iletişim becerilerini araştırmacı yaklaşımla temel alan bir uygulamadır. Adli Muhasebe mesleği pek çok batı ülkesinde geleceğin gözde meslekleri arasında kabul edilen ve özellikle dolandırıcılık suçlarının soruşturulmasında son derece önemli katkılar sağlayan saygın bir meslektir (Aktaş ve Kuloğlu, 2008: 102). Adli muhasebe, muhasebe meslek mensupları için geniş kariyer firsatları sunan bakir bir alandır.

\subsection{Adli Muhasebe Mesleğinin Uygulama Alanları}

Adli muhasebe, bazı araştırmacılar tarafından; muhasebecilik-hile denetçiliği ve dava destek danışmanlığı olarak iki temel alana ayrılırken (Kaya, 2005: 52), bazı araştırmacılar, adli muhasebenin uygulama alanlarını; muhasebecilik-hile denetçiliği, dava destek danışmanlığı ve uzman şahitlik şeklinde üçe ayırmaktadırlar (Toraman ve diğerleri, 2009: 37; Pazarçeviren, 2005: 4). İkili sınıflandırmada uzman tanıklık faaliyetleri, dava destek danışmanlığının bir alt kolu olarak değerlendirilmektedir. Bu çalışmada, üçlü sınıflandırma benimsenmiştir.

Araştırmacı Muhasebecilik-Hile Denetimi; Hile denetimi hukuki sorgulama yöntemleri ile standart denetleme tekniklerini birleştiren yeni bir alandır. Hile denetimi, firma temelinde elde edilecek bilgilerin yanında hilelerin değişik sektörlerde nasıl ortaya çıkacağıyla ilgili bilgiye ve tecrübeye sahip kişilerce yürütülür (Emir, 2008: 110). Hile denetimi bir yerde, işletmelerde hilelerin ortaya çıkarılması ve önlenmesi; verimliliğin artırılması, işletme faaliyetlerinin sağlıklı bir şekilde yürütülebilmesi için, önemli hile ve yolsuzlukların zamanında ve çok büyük kayıplara neden olmadan tespit edilebilmesi ile ilgili çalışmalardır(Çankaya ve Gerekan, 2009: 94-95; Çabuk ve Yücel, 2012: $35)$.

Dava Destek Danışmanlığı; Dava destek danışmanlığı, adli muhasebe mesleğinin uygulanması noktasında bir dava öncesinde ya da dava sürerken ilgili yargı makamlarına ya da avukata sağlanan uzman destek hizmetidir. Dava destek danışmanlığı daha çok olayın ekonomik boyutuyla ilgilenilir. Taraflar arasında yapılan bir sözleşmeye aykırı hareket edilmesi ya da herhangi bir ihmal, ihlal sonucunda ortaya çıkan bir mali kaybın hesaplanması adli muhasebeci tarafından sağlanan dava desteğine tipik bir örnektir (Karacan, 2012:113). Dava destek danışmanlığı hizmeti kapsamında adli muhasebeciler tarafindan sunulan hizmetler; mesleki sorumluluk davaları kapsamında, herhangi bir 
inşaatın geciktirilmesi, ticari sırların çalınması, sigorta anlaşmazlıkları, hasar ve zarar tahminleri gibi olaylardan kaynaklanan kayıpların hesaplanması, hukuki davalar olarak adlandırılan; boşanmalarda yapılması gereken işletme değerlemeleri, çalışanların hırsızlığı ve iş gören kazası ile diğer kaza soruşturmaları olarak sayılabilir (Kaya, 2005: 53). Ayrıca tipik bir dava destek danışmanlığı hizmeti genellikle sözleşme ihlalinden kaynaklanan ekonomik kayıpların hesaplanmasını da içermektedir (Özkul ve Pektekin, 2009: 65).

Uzman Tanıklık; Uzman tanıklık, orijinal dilinde "Expert Witness" olarak adlandırılmaktadır. Kavram, dilimize uzman şahitlik ya da uzman tanıklık olarak çevrilmiştir. Ancak kavramın içeriği incelendiğinde hukukumuzdaki bilirkişilik kurumunu benzediği görülmektedir. Aşağıda bu kavram daha geniş olarak ele alınmıştır.

\section{3. Uzman Tanıklık}

Bir adli muhasebe uygulama alanı olan uzman tanıklık; mahkemeye intikal etmiş birtakım konuların değerlendirilmesi, ilgili yasal mevzuata uygun bir şekilde sonuca ulaşılması ve varılan sonucun hem yazılı, hem de sözel olarak mahkeme heyetine sunulmasıdır (Karacan, 2012: 115). Uzman tanık; görgü şahidinin aksine gördüklerini, duyduklarını, hissettiklerini değil uyuşmazlığa ait görüşlerini kendi eğitim, deneyim ve uzmanlığına dayanarak ifade eden kişidir (Murray, 2009: 20). Uzman tanıklık, özel ve teknik bir konuda bilgi sahibi olan ve mesleki tecrübesi bulunan kişilerin yürüttüğü faaliyettir ve hakkında bilgi verilen olayın içinde olma ya da olayı gözlemleme şartı aranan görgü tanıklı̆̆ından mesleki ve teknik bilgi ile tecrübe ihtiyacı unsurları sayesinde ayrılmaktadır (Çoban, 2013: 51).

Uzman tanıklığa duyulan ihtiyacın temelinde mesleki uzmanlaşma olgusu ve ticari hayatın giderek daha fazla karmaşıklaşması sorunu yer almaktadır. Hakimler, yargıya taşınan konuların hukuksal yönünde uzman olmalarına rağmen konunun olgu yönünü oluşturan ticari işlemler ve muhasebe alanında yeterli bilgi sahibi değildir. Ayrıca kendilerinden bu konularda genel kültür düzeyinin üzerinde bilgi sahibi olmalarını istemek doğru değildir. Bu nedenlerle yargı mensupları çözüme kavuşturmaları gereken mali konulu davaların özel bilgiyle yorumlanması gereken kısımlarında bu alanda deneyimli bir uzman tanığın görüşlerinden yararlanabilmektedir (Çoban, 2013: 52). Bu durumda, dava taraflarının konusunda uzman bir avukata ya da avukat grubuna sahip olması kadar kendi uzman şahidine sahip olması da bir davanın kazanılması ya da kaybedilmesinde önemli derecede etkiye sahip olabilmektedir (Squar, 2009, 28).

Özünde adli muhasebeci olan uzman tanıkların diğer meslek uygulayıcılarından farklı olarak bazı kişilik özelliklerine ve uzmanlık bilgisine sahip olmaları gerekmektedir. Bu özellikler, merak, 1srarcılık, yaratıcılık, sezgi ve iletişim becerisi olarak sıralanabilir. (Bozkurt, 2000: 59):

AICPA'ya göre bir adli muhasebeci olan uzman tanığın sahip olması gereken beceri ve nitelikler, dört grupta toplanmaktadır. Birinci grup özellik, yeterli eğitim ve deneyim ile ilgilidir. 
Uzman tanık, genel kabul görmüş muhasebe prensipleriyle ilgili deneyim ve uygulama, vergi hukuku, genel işletme hukuku ve meslek etiğinde yeterli seviyede bilgiye sahip olmalıdır. İkinci grup özellik, temel adli bilgi yeterliliğidir. Uzman tanık; mesleki sorumluluk ve uygulama yönetimi, yasalar, mahkemeler, uyuşmazlık çözümü, planlama ve hazırlık becerileri, bilgi toplama ve topladığı bilgileri saklama, keşfetme becerisi ve raporlama konusunda yeterli olmalıdır. Üçüncü grup özellik, adli becerilerde uzmanlaşmadır. Dördüncü grup özellik ise, analiz ve sonuç çıkarma yeteneğidir. Uzman tanık, iflas, ödeyememe aczi, borç yenileme konularında kazanılmış bilgi, bilgisayarlı adli analiz, aile hukuku, değerleme, hile önleme ve tespiti, gerçeğe aykırı finansal beyan, ekonomik zarar hesaplama yetenekleri konusunda yeterli olmalıdır. (Davis ve diğerleri, 2009: 3-4):

Uzman tanıkların görev alanları mahkemeler olduğu için etkili bir yazılı ve sözlü iletişim yeteneğine sahip olmaları işin olmazsa olmazıdır. Bir uzman tanığın görevi uzmanlık alanına giren konularda gerçeklerin ortaya çıkarılmasını sağlamaktır. Uzman tanıklar, kendilerini görevlendiren ya da kendilerine ücret ödeyen kişilerin yasaya aykırı fiilleri işlemeleri halinde bu kişilerin menfaatini korumak zorunda değildirler (Larosa, 2009:1 ). Uzman tanıkların bilgi sahibi olmaları gerekli alanlar; adli yarg1, muhasebe, hukuk, denetim, işletme yönetimi, psikoloji, suç bilimi, bilgisayar uygulamaları şeklindedir. Ayrıca uzman tanık olabilmek için kişi öncelikle yeterli eğitime sahip olmalıdır (Hoffman, 2002: 380).

\subsection{Uzman Tanıklık ve Bilirkişilik Kurumunun Karşılaştırılması}

Bilirkişiler ilgili yargı mercii tarafından görevlendirilen meslekle ilgili kişilerdir. Ancak bilirkişilik uygulaması adli muhasebecilik ile eş tutulabilecek kadar geniş kapsamlı değildir Çünkü uzman tanıkların bilirkişilere göre daha geniş yetkinliklere ve kişisel özelliklere sahip olması gerekmektedir. Uygulamadaki şekliyle bilirkişilik yapabilmek için, ilgili konuda çalışmalar yapmış olmak, belirli bir eğitim seviyesine sahip olmak gibi genel kriterler yeterli olmaktadır. Ancak adli muhasebeci uzman tanıkların bu genel kriterleri taşımanın yanında ilave bazı özel kriterleri de taşımaları gerekmektedir (Karacan, 2012: 124).

Uzman tanıklığa ve bilirkişiliğe duyulan ihtiyaç temelde aynıdır. Bu iki meslek grubunu birbirinden ayıran temel farklılıklar bulunmaktadır. Bu farklılıklar aşağıda özetlenmeye çalışılmıştır (Çoban, 2013:75).

- Uzman tanıklar, bilirkişilere nazaran daha araştırmacı, şüpheci, sezgisel, analitik düşünebilen ve etkili sözel iletişim yeteneğine de sahip kişilerdir.

- Türkiye'de bilirkişilik için genelde YMM, SMMM ve $\mathrm{SM}^{2}$ ünvanlarından birine sahip olmak yeterli görülürken, Uzman tanıkların; adli muhasebe alanında uzman olduklarını belgeleyen Sertifika sahibi olmaları beklenir.

\footnotetext{
${ }^{2}$ Serbest Muhasebecilik (SM) mesleği temmuz 2008 de yayımlanan 5786 Sayılı Kanun'la kaldırılmıştır.
} 
- Bilirkişiler Türkiye'de mahkemelerce görevlendirilirlerken uzman tanıklar mahkemelerin yanında hukuk büroları ve şirketler tarafindan da görevlendirilebilmektedirler. Tarafların her biri kendi uzman tanığına sahip olabilir.

- Çalışma sürecinde bilirkişiler kendilerine gönderilen dosyada sadece kendilerinden istenen konuyu inceler, araştırma yapamamakta ve kendisine sunulan belgelerden başka belgeleri kullanmazlar. Uzman tanıklar ise çalışmalarını bir dedektif edasıyla yürütürler ve konuyu bir bütün olarak ele alarak kendisini destekleyecek kanıt elde etmeye çalışırlar.

- Uzman tanıklar çalışmalarını mahkeme heyetine sunarken yazılı rapor vermenin yanında sözlü savunma da yapabilir ve savunması sırasında modern sunum tekniklerini kullanabilirler. Ayrica uzman tanıklar, duruşma sırasında karşı tarafın avukatınca çapraz sorguya alınabilir. Bilirkişiler ise dosya üzerinden yürüttükleri incelemeleri sadece yazılı rapor halinde mahkemeye sunmaktadırlar. Bu sebeple uzman tanıklar gibi mahkeme ortamının gereklerine uyum sağlama yükümlülükleri bulunmamaktadır.

\section{ARAȘTIRMA}

\section{1. Araștırmanın Amacı ve Yöntemi}

Uzman tanıklık mesleği, bilirkişilik müessesesinin yerine alabilecek, mevcut sistemin sorunlarına bir nebze olsun çözüm olabilecek yeni bir mekanizmadır. Ancak, bu yeni mekanizmanın istenen sonucu verebilmesi, bu mekanizmayı çalıştıracak uygulayıcılara bağlıdır. Bu uygulayıcılar ise büyük oranda, muhasebe meslek mensuplarıdır. Adalet uygulayıcılarının böyle yeni bir sisteme ihtiyaç duyup duymadıkları ve mevcut muhasebe meslek mensuplarının bu yeni sisteme ne kadar yatkın oldukları bilinmemektedir. Bu nedenle, bu çalışma, mevcut adalet uygulayıcılarının uzman tanıklık mesleğinin gerekli olup olmadığı ne düşündükleri ve bu mesleği icra etmesi muhtemel olan muhasebe meslek mensuplarının bu konudaki yeterliliklerini ortaya koymaya odaklanmıştır.

Araştırma iki aşamalı anket yöntemi ile gerçekleştirilmiştir. Araştırmanın birinci aşaması adalet sisteminin uygulayıcıları olan hakimler üzerinde gerçekleştirilmiştir. Bu amaçla İstanbul'da görev yapan 100 hakimden randevu talep edilmiş ancak bu hakimlerden sadece 60'i ile yüz yüze görüşme imkanı bulunabilmiştir. Bu görüşmeler esnasında, daha önce hazırlanan anket sorularına doğrudan cevaplar alınmıştır. Hakimlere sunulan anket soruları iki bölümden oluşmuştur. Birinci bölümünde hakimlere; bilirkişilik sisteminin günümüz yargısı için yeterli olup olmadığı, uzman tanıklığa ihtiyaç duyulup duyulmadığı ve muhasebe meslek mensuplarının uzman tanıklık yapıp yapamayacakları sorulmuştur. İkinci bölümde ise hakimlerin muhasebe meslek mensuplarının uzman tanıklık mesleğini icra etmede yeterli olup olmayacakları hususunda ne düşündüklerini ortaya koyacak sorular yer almıştır. Bu bölümdeki sorular, anketin ikinci aşamasında muhasebe meslek mensuplarına yönelik olarak hazırlanan sorularla aynıdır. $\mathrm{Bu}$ şekilde, hakimlerle muhasebe meslek mensuplarının düşünceleri karşılaştırılabilecektir (Ek:1ve EK:2, Anket formları). 
Araştırmanın ikinci aşaması muhasebe meslek mensuplarına yöneliktir. Anketin uygulanmasında, internet ve geleneksel elden bırakıp alma yöntemleri kullanılmıştır. İnternet anketinin yürütülebilmesi için muhasebe meslek mensuplarının üye olduğu mesleki paylaşımı ve birlikteliği amaçlayan Google grupları araştırılmış ve ilgili gruplara üyelik başvurusunda bulunulmuştur. Daha sonra bu gruplar aracılığı ile muhasebe meslek mensuplarına hazırlanan internet anketinin adresini içeren bir davet metni elektronik posta ile gönderilmiştir. Geleneksel anket türlerinden elden bırakıp alma yöntemi ise Ankara, İstanbul ve Trabzon illerinde uygulanmıştır. Araştırmanın diğer illerde yapılamamasının önemli bir nedeni maliyet kısıtıdır. Bu nedenle, araştırma ekonomik imkanlar çerçevesinde bu üç ilde yapılmıştır.

Araştırmanın ikinci aşamasında uygulanan anket formu, iki bölümden oluşmuştur. Birinci bölüm; katılımcıların demografik özelikleri sorgulayan nominal ölçekli on sorudan oluşturulmuştur. İkinci bölümde ise uzman tanıklık mesleğini icra edecek olan muhasebe meslek elemanlarının bu konudaki yeterlilikleri hakkında ne düşündüklerini ortaya koymaya yönelik kırk sekiz soru yer almıştır. Soruların belirlenmesinde adli muhasebe ve bilirkişilik alanında yapılan literatür taramasından yararlanılmış ve çoklu ölçek türlerinden beşli ölçek kullanılmıştır. Ölçeğin sıralaması; "1- Çok Kötü, 2-Kötü, 3-Orta, 4-İyi, 5- Çok İyi” şeklinde belirlenmiştir.

\subsection{Araştırmanın Evreni ve Örnekleme}

Sosyal bilimler literatüründe 30'dan büyük 500'den küçük örnek büyüklüğü birçok araştırma için yeterlidir (Altunışık ve diğerleri, 2007: 127). Buna göre, araştırmanın birinci aşamasında ulaşılan 60 kişilik örneklem sayısı çalışma kapsamında yürütülen araştırma için yeterli görülmüştür. Araştırmanın birinci aşamasında, örnekleme tekniği olarak olasılığa dayalı olmayan örnekleme tekniklerinden kolayda örnekleme tekniği kullanılmıştır.

Araştırmanın ikinci aşamasında araştırmanın evreni Türkiye'de faaliyet gösteren muhasebe meslek mensupları olarak belirlenmiştir. Araştırmanın evrenine ilişkin bilgiler TÜRMOB'un internet sayfasından elde edilmiştir. TÜRMOB'un 05.10.2012 tarihli SM ve SMMM Meslek Mensubu Dağılım Tablosuna göre Türkiye'de faaliyette bulunan SM sayısı 12.620, SMMM sayısı ise 72.450'dir. TÜRMOB'un 05.10.2012 tarihli YMM Meslek Mensubu Dağılım Tablosuna göre Türkiye'de faaliyette bulunan YMM sayıs1 4.046'dır (Türkiye Serbest Muhasebeci Mali Müşavirler ve Yeminli Mali Müşavirler Odaları Birliği [TÜRMOB], 2012; Meslek Mensubu Dağılım Tablosu SM ve SMMM; TÜRMOB, 2012; Meslek Mensubu Dağılım Tablosu YMM). Araştırmanın evrenini Türkiye'de faaliyette bulunan 89.116 muhasebe meslek mensubu oluşturmaktadır. Sosyal bilimler literatüründe belirli evrenler için kabul edilebilir örnek büyüklüklerine bakıldığında 75.000 say1lı ana kütle için kabul edilebilir örneklem sayısı 382 iken, 100.000 sayılı ana kütle için kabul edilebilir örneklem sayısının 384 olduğu görülmektedir (Altunışık ve diğerleri, 2007: 127). Bu kapsamda, elektronik posta ve elden bırakıp toplama usulü ile 1500 kişiye ulaşılmış ancak bunlardan ancak 495 
tanesinden cevap alınabilmiştir. Ulaşılan bu sayı sosyal bilimler literatüründe belirli evrenler için kabul edilebilir örnek büyüklüklerine uygundur.

\subsection{Geçerlilik ve Güvenilirlik}

Geçerlilik, bir test veya ölçeğin ölçülmek istenen şeyi ölçme derecesidir. Uygulamada çok çeşitli geçerlilik testleri geliştirilmiştir. Bunlardan bir tanesi de içerik geçerliliğidir. İçerik geçerliliğ̣i; anketin yeterli sayıda ve ölçülmek istenen olguyu temsil edebilecek soruları içerdiğinden emin olunmasıdır. Bu amaçla kavramın öğelerinin ve boyutlarının ölçekte ne derece yer aldığı belirlenir (Altunışık ve diğerleri, 2007: 113). Araştırmanın soruları literatür taramasına dayanarak hazırlanmış ve alanında uzman kişilerden sorular hakkında görüş alınarak soruların düzeltilmesi yoluna gidilmiştir. Anket formundaki soruların cevaplayıcılar tarafından tam ve doğru bir biçimde anlaşılabilmesi için Trabzon ilinde pilot çalışma yapılmıştır. Anket formunda tespit edilen aksaklıklar bu yolla giderilmiştir.

Güvenilirlik; bir testin veya ölçeğin ölçmek istediği şeyi tutarlı ve istikrarlı bir biçimde ölçme derecesidir. Güvenilir bir test veya ölçek benzeri şartlarda tekrar uygulandığında benzeri sonuçlar vermelidir. Güvenilirlik kavramı ölçekte yer alan tesadüfi hatalarla ilgilidir, sistematik hataların güvenilirlik üzerinde etkisi bulunmamaktadır. Eğer bir araştırmada kullanılan ölçüm aracı farklı şartlar altında benzeri sonuçlar veriyorsa ve farklı araştırmacılar tarafından farklı durumlarda benzeri gözlemler yapılıyorsa araştırmanın güvenilir olduğu söylenir (Altunışık ve diğerleri, 2007: 114-115). Araştırmanın güvenilirliğini ölçmek amacıyla içsel tutarlık analizi kullanılmıştır. İçsel tutarlılığın ölçümünde en yaygın kullanılan yöntem Cronbach Alfa olarak da adlandırılan Alfa Katsayısıdır. Çalışmada Alfa Katsayısı kullanılmıştır. Alfa Katsayısı 0-1 arasında değer almaktadır. Kabul edilebilir değerin en az 0,70 olması gerekmektedir. Araştırmanın ilk aşamasında Alfa Katsayısı 0.963 iken ikinci aşamasında Alfa Katsayısı 0,945'tir. Bu bulgular anketten elde edilen verilerin güvenilirliğinin oldukça yüksek olduğunu göstermektedir.

\section{Literatür Taraması}

$\mathrm{Bu}$ çalışmanın konusu ile alakalı, yerli ve yabancı yazında yer alan teorik ve uygulamalı çalışmalar aşağıda kısaca özetlenmiştir.

Yabancı literetürde konuya en yakın çalışmalardan biri, Digabriele ve diğerleri (2008) yaptıkları çalı̧̧mada, adli muhasebecilere, çalışma alanları adli muhasebe olan akademisyenlere ve adli muhasebe hizmetlerinden yararlanan avukatlara bir adli muhasebecinin hangi yeteneği öncelikle kazanmasının önemli olduğu sorulmuş ve böylece üniversitelere, adli muhasebe müfredatını hazırlamaları esnasında yol gösterici önerilerde bulunabilmek amaçlanmıştır. Araştırma kapsamında belirlenen adli muhasebeci özellikleri; tümden gelim analizi yapabilme becerisi, kritik düşünme becerisi, problem çözme becerisi, esnek soruşturma yürütebilme becerisi, yazılı iletişim yeteneği, sözel iletişim yeteneği, özel hukuk bilgisi, soğukkanlılık şeklinde sıralanmaktadır. 
Bir diğer araştırmada ise Davis ve diğerleri (2009), etkili bir adli muhasebecinin sahip olması gereken özellikleri belirlemeye çalışmışlardır. Araştırma kapsamında yürütülen anket uygulamasında katılımcılar; Avukatlar, Akademisyenler ve Sertifikalı Kamu Muhasebeciler (CPA) olarak belirlenmiş. Çalışmada katılımcılardan bir adli muhasebecinin sahip olması gereken uzmanlık alanlarını, nitelikleri ve kişisel özellikleri, temel özellikleri, gelişmiş becerileri, önem sırasına göre sıralamaları istenmiştir. Çalışmada uzmanlık alanları; mali tabloların yanlış beyanı, ekonomik zarar hesaplama, hile önlemetespit etme, hileye karşı verilecek tepkiler, değerleme, aile hukuku, iflas ve ödeme aczi işlemleri hakkında bilgi, bilgisayarda adli muhasebe analizi şeklinde sıralanmıştır. Sahip olunması gereken nitelik ve kişisel özellikler; analitik düşünce tarzı, detay odaklılık, etik, hızlı tepki verebilme, anlayışlı olma, merak, sezgisellik, 1srarcılık, şüphecilik, dikkatli değerlendirme yapabilme, baskı altında çalışabilme, yeni fikir ve senaryo geliştirebilme, kendine güven, insanları yatıştırabilme, takım çalışmasına yatkınlık, uyumluluk olarak sıralanmıştır.

Yerli yazında konuyla ilgili çalışmada ise, Bozkurt (2000), ülkemizde uygulaması olmayan adli muhasebe mesleğinin kapsamını ve özelliklerini tanıtmış ve bir adli muhasebecinin taşıması gereken özellikler de incelenmiştir. Adli muhasebecinin normal eğitim yanında bazı disiplinlerde etkili bilgi birikimine sahip olması gerektiği vurgulanmıştır. Bu disiplinler; yoğun bir muhasebe bilgisi, hukuk, denetim, işletme yönetimi, psikoloji, suç bilimi, bilgisayar uygulamaları şeklinde sıralanmıştır. Adli muhasebecinin taşıması gereken kişisel özellikler ise merak, 1srarcılık, yaratıcılık, sezgi, hüner olarak belirtilmiştir.

Başka bir çalışmada Kaya (2005), Türkiye'de adli muhasebenin niçin ve nasıl uygulanması gerektiği üzerinde durmuştur. İlgili makalede; adli muhasebenin, gerek ülke düzeyinde hukuk sisteminin sorunlarının çözümünde gerekse işletme düzeyinde görülen hile ve yolsuzluklarla mücadelede uygulayıcılara yardımcı olacağı vurgulanarak adli muhasebenin ülkemiz açısından bir ihtiyaç olduğu kanısına yer verilmiştir.

Pazarçeviren (2005) ise yaptığı çalışmada, adli muhasebe mesleğinin kapsamı ve özellikleri hakkında bilgi verilmiş ve adli muhasebe mesleğinin toplumun muhasebecilere bakış açısını değiştirdiğinden ve adli muhasebeciler ile genel standartlara göre eğitilmiş muhasebeci, denetçiler arasında önemli nitelik farkları olduğundan bahsetmiştir.

Konuyla ilgili bir diğer çalışmada Özkol (2005), bilirkişilik ve adli muhasebecilik mesleğinin karşılaştırması yapılmıştır. Bilirkişinin sahip olması gereken özellikler; uzmanlık, yeterlilik, tarafsızlık ve dürüstlük olarak sıralanarak adli muhasebeci ve bilirkişiler arasındaki farklara değinilmiştir.

Kuloğlu (2007) ise, ülkemizdeki kredi kartı dolandırıcılığı soruşturma süreci ile adli muhasebenin önermekte olduğu soruşturma sürecini karşılaştırarak, benzerlik ve farklılıklar ortaya konulmaya çalışılmıştır. Çalışmada adli muhasebecinin sahip olması gereken özelliklere de değinilmiştir. Bu özellikler ve bilgi birikimleri; dolandırıcılık bilgisi, hukuk bilgisi, delil kuralları, 
soruşturma yeteneği, toplumsal beceriler, psikoloji teorileri ve ceza davranışına ilişkin teorileri anlama yeteneği, iletişim becerileri, bilgi teknolojisi becerileri, deneyim, finansal analiz, işlemlerin ve uygulamaların denetimi ve değerlendirilmesi, risklerin saptanması, bağımsızlık, mesleki yeterlilik şeklinde sıralanmıştır.

Başka bir çalışmada ise, Çankaya ve Gerekan (2009), adli muhasebenin bir uzantısı olarak ele alınan hile denetçiliği mesleğinin tanıtılması amaçlanmıştır. Bu maksatla ülkemizde mesleğin geliştirilmesine 1şık tutması bakımından merkezi ABD'de bulunan ACFE tarafından meslekle ilgili geliştirilmiş standartlar ve meslek ahlak kuralları ortaya konmuştur. Ayrıca ülkemizde mevcut olan iç denetim standartları ve meslek ahlak kuralları ile ACFE hile denetçiliği standart ve ahlaki kurallarının kıyaslaması yapıldıktan sonra mesleğin gelişimi için önerilerde bulunulmuştur. Çalışmanın sonuç kısmında ise ülkemiz açısından mesleğin gelişimi için gerekli eğitim şartları sağlanması gerektiği ve bu alanda hizmet veren bir kuruluşun tayin edilmesi ve gerekli hukuksal düzenlemelerin yapılması şeklinde önerilerde bulunulmuştur.

Kurt ve Uçma (2009) yaptıkları çalışmada küresel dünyada artan teknolojik olanaklar ile birlikte karmaşıklaşan ticari iş süreçleri ve buna bağlı olarak artan finansal nitelikteki suç faaliyetlerinin çözümünde yargı mensupları ve suç bilimi araştırmacılarının yetersiz kalmaları sebebiyle adli muhasebecilere ihtiyaç duyulduğu belirtilmiş. Bu noktada doğan ihtiyaca cevap verebilmek için belirli eğitim, deneyim ve bilgi düzeyine sahip, alanında yetkin, hukuk, suç bilimi, sosyoloji, psikoloji, bilgisayarlı soruşturma teknikleri ve birçok hukukun alt alanını içerisinde barındıran, iyi bir mesleki uzmanlık ve denetim bilgisi ile donanmış meslek elemanlarına ihtiyaç olduğundan bahsedilmiştir. Ayrıca çalışmada Türkiye ve ABD'de adli muhasebecilik mesleği uygulamaları ve meslek mensubu olma süreçleri detaylı olarak incelenmiştir.

Özkul ve Pektekin (2009) ise yaptıkları çalışmada, bilgi teknolojilerinin, muhasebe denetiminde artan önemine vurgu yaparak teknolojinin negatif amaçlarla kullanıldığı durumlarda ortaya çıkan yolsuzluklar ve bu yolsuzlukları tespit etmede ve önlemede adli muhasebecinin yararlanabileceği veri madenciliği tekniklerine yer verilmiştir. Çalışmada ayrıca adli muhasebecinin taşıması gereken özelliklere de değinilmiştir.

Bir diğer çalışmada Akyel (2009), adli muhasebeciliğin altyapı bileşenleri olarak sıralanan hukuk, muhasebe, suç bilimi ve eğitim sistemlerinin Türkiye'deki mevcut durumları gözden geçirilerek, adli muhasebeciliğin uygulanabilirliği değerlendirerek, Türkiye açısından bir eğitim modeli önerisi geliştirilmiştir.

Pehlivan (2010) ise yaptığı çalışmada, gelişmiş ülkelerde geniş bir uygulama alanı bulan adli muhasebe uzmanlık eğitiminin ulaştığı seviyeyi ortaya koyduktan sonra Türkiye'deki akademisyenlerin adli muhasebe eğitimine bakış açılarının tespit edilmesine yönelik anket çalışması 
yapılarak, adli muhasebe ile ilgili Türkiye'de yeterli bir eğitim altyapısının bulunmadığı sonucuna varılmıştır.

Türk literatüründe yapılan çalışmalardan birinde Şahin (2011), adli muhasebecilik mesleği tanıtarak, 6102 Sayılı Türk Ticaret Kanunu ve adli muhasebe mesleği arasındaki ilişki incelemiştir. Türkiye'deki adli muhasebecilik mesleğinin uygulanışı ortaya konulmaya çalışılmış ve 6102 Sayılı Türk Ticaret Kanunu'nun adli muhasebe mesleğine Kanun'un çeşitli maddelerinde değinildiği ancak bunun adli muhasebecilik mesleğinin kabulü açısından yeterli olmadığı sonucuna varılmıştır. Ayrıca Türkiye'de adli muhasebeciliğin meslek olarak kabul edilmesi için, meslek mensuplarının sertifika sahibi yapılması ve adli muhasebe eğitiminin gerek lisans ve lisansüstü seviyede gerekse de meslek mensuplarına sertifika sahibi olmalarından sonra mesleki yetkinliklerini devam ettirmeleri amacı ile sürekli eğitim verilmesi gerektiğinden söz edilmiştir.

Usul ve Topçuoğlu (2011) ise yaptıkları çalışmada, teknolojideki hızlı gelişimin mali suçların oluşum şeklini ve yapısını değiştirdiğinden ve bu tür suçların ortaya çıkarılmasında, başlangıcında ve önlenmesinde yeni tekniklerin kullanımının zorunluluk haline gelmesi sebebiyle adli muhasebe mesleğine ihtiyaç duyulduğundan bahsedilmiş. Adli muhasebecilik mesleğinin, günümüzde mali suçların ortaya çıkarılmasında adli makamlara hizmet verdiğine ve böylece adaletin hızlı ve doğru bir şekilde oluşmasına yardımcı olduğuna değinilerek adli muhasebenin hukuk sistemimizde var olması gerekliliği üzerinde durulmuştur.

Çabuk ve Yücel (2012) adli muhasebenin önemi doğrultusunda, adli muhasebecilik mesleğinin kapsamı ve gelişimi inceleyen bir çalışma yapmışlardır. Ayrıca sözkonusu çalışmada sermaye piyasasında bağımsız denetime yetkili kuruluşların bakış açılarıyla Türkiye'de adli muhasebecilik mesleğinin mevcut durumu analiz edilmiştir. Analiz sonucunda ülkemizde mevcut denetim sisteminin, adli muhasebe için gerekli alt yapının ve eğitim sisteminin yetersiz olduğu tespit edilmiş ve mesleğin gelişimi için yapılması gereken faaliyetler değerlendirilmiştir.

Elitaş (2012) ise adli muhasebecilik mesleğinin gerekliliği ve adli muhasebenin yasal dayanağı konularını inceleyen bir çalışma yapmıştır.

Pehlivan ve Dursun (2012) yaptıkları çalışmada; Türkiye'deki akademisyenlerin adli muhasebe eğitimine bakış açılarının tespit edilmesine yönelik anket çalışması yapılarak, adli muhasebe ile ilgili Türkiye'de yeterli bir eğitim altyapısının bulunmadığı sonucuna varılmıştır.

Mevcut literatür incelendiğinde, çalışmaların büyük çoğunluğunun adli muhasebe eğitimi ve adli muhasebecinin özellikleri üzerinde durduğu görülmektedir. Bu açıdan, uzman tanıklık mesleği baz alınarak yapılan bu çalışma, alanında ilk çalışma olma özelliği taşımaktadır. 


\section{Bulgular}

\subsection{Faktör Analizi}

Muhasebe meslek mensuplarının uzman tanıklık mesleğini icra edip edemeyeceklerine yönelik yeterliliklerini ortaya koymak amacıyla sorulan soruların fazla oluşu, aralarındaki muhtemel yüksek derecedeki çoklu doğrusal bağlantı, hesaplama sonucu elde edilen bulguların doğruluğunu ve yorumlanmasını güçleştirmektedir. Böyle durumlarda, toplam değişkenlerin içerdiği bilgiyi maksimum düzeyde açıklayabilecek daha az sayıdaki boyuta indirgemek uygun bir yöntemdir. $\mathrm{Bu}$ doğrultuda, muhasebe meslek mensuplarına yönelik olarak hazırlanan ve anket yolu ile tespit edilen değişkenler, faktör analizi uygulanarak bazı ana bileşenler elde edilmiştir. Çalışmada, Ana Bileşenler Faktör Analizi kullanılmıştır. Faktör analizi sonucunda elde edilen yeni skor değerleri, başka analizlerde kullanılabilmektedir (Mc Daniel ve Gates, 1996:612).

Anket formunun ikinci bölümünde yer alan soruların fazla sayıda olması analizi güçleşdiğinden, bu 48 soru daha az sayıda alt faktörlere indirgenmesi gerekli görülmüştür. İlk analizde öncelikle bir değişkenin analizdeki diğer değişkenlerle paylaştığı veri miktarını ifade eden değişkenlerin ortak varyansı ölçütü dikkate alınarak; değişkenlerin ortak varyansı değeri 0,50'nin altında olan sorular analizden çıkartılmıştır. İlk faktör analizinde ikinci olarak verilerin hangi faktör altında gruplandığını göstermek için yapılan "Rotasyon Aşamasında", "Dönüştürülmüş Faktör Matrisi Tablosundaki” her bir değişkenin faktörler altındaki ağrılıkları incelenmiştir. Bu tabloda faktör ağılıkları 0,50'nin altında olan sorular da analizden çıkartılmıştır. Böylelikle veri seti faktör analizine uygun hale getirilmiştir. Daha sonra geri kalan otuz sekiz soruya ait veriler ikinci kez faktör analizine tabi tutulmuştur. Veri setinin faktör analizi için uygun olup olmadığını belirlemek amacıyla KMO Testi ve Barlett Testi uygulanmıştır. Veri setinin faktör analizine uygun olması için KMO Test sonucunun 0,50'den büyük olması ve Barlett Testi sonucu elde edilen p değerinin 0,05'ten küçük olması gerekmektedir. Tablo 1 'de görüldügü üzere KMO Testi sonucu 0,926 'dır ve değişkenler arasındaki korelasyonu gösteren Barlett Testi sonucu elde edilen p değeri 0,00 'dır. Bu sonuçlar, analiz yapılacak verilerin faktör analizine uygun olduğunu göstermektedir.

Tablo 1. KMO ve Bartlett Testi Sonuçları

\begin{tabular}{|l|l|l|}
\hline KMO & 0,926 \\
\hline Bartlett Testi & Ki kare & 10702,088 \\
\hline & Sd & 703 \\
\hline & P & 0,000 \\
\hline
\end{tabular}

Faktör analizinin ikinci aşamasında değişkenlerin ortak varyansı değerleri incelenmektedir. Değişkenlerin ortak varyansı, bir değişkenin analizdeki diğer değişkenlerle paylaştığı veri miktarını ifade etmektedir. Eldeki veri setiyle faktör analizine devam edebilmek için ortak varyans değerlerinin 0,50'den büyük olması gerekmektedir. Çalışmadaki değişkenlerin ortak varyansı değerleri 0,50'nin üzerindedir ve veri setinde faktör analizinden çıkarılacak soru bulunmamaktadır. Faktör analizinin 
üçüncü aşaması faktör sayısının belirlenmesidir. Özdeğer istatistiği değeri 1'den büyük olan faktörler anlamlıdır. Buna göre özdeğer istatistiği 1'den büyük olan 8 faktör belirlenmiştir. Faktörler toplam varyansın \% 65,434'ünü açıklamaktadır. 1. faktör toplam varyansın \%10,709'unu, 2. faktör \%10,633'ünün, 3. faktör \%10,079’unu, 4. faktör 9,837'sini, 5. faktör 9,157'sini, 6. faktör 7,299’unu, 7. faktör 4,164'ünü, 8. faktör \%3,5572'sini açıklamaktadır. Bu 8 faktörün, güvenilirlik dereceleri ise sırasıyla, $0.908,0.700,0.866,0.838,0.807,0.807,0.684$ ve 0.784 dür. Bu sonuçlar, faktörleri oluşturan değişkenlerin kendi içlerinde de güvenilir olduklarını göstermektedir.

Tablo 2. Dönüştürülmüş Faktör Matrisi Tablosu

\begin{tabular}{|c|c|c|c|c|c|c|c|c|}
\hline \multirow[b]{2}{*}{ Değişkenler } & \multicolumn{8}{|c|}{ Faktörler } \\
\hline & 1 & 2 & 3 & 4 & 5 & 6 & 7 & 8 \\
\hline İç kontrol bilgim... & 0,798 & & & & & & & \\
\hline İç denetim bilgim... & 0,785 & & & & & & & \\
\hline Bağımsız (dış) denetim bilgim... & 0,729 & & & & & & & \\
\hline Hile tespit etme yeteneğim... & 0,710 & & & & & & & \\
\hline Kanıt toplama hakkında bilgim... & 0,621 & & & & & & & \\
\hline Risk değerleme bilgim... & 0,619 & & & & & & & \\
\hline Soruşturma yürütebilme becerim... & & 0,778 & & & & & & \\
\hline Psikoloji bilgim... & & 0,753 & & & & & & \\
\hline Suç bilimi (kriminoloji) bilgim... & & 0,736 & & & & & & \\
\hline Adli sürecin işleyişi hakkında bilgim... & & 0,723 & & & & & & \\
\hline Bilişim teknolojiler hakkındaki bilgim... & & 0,653 & & & & & & \\
\hline Kanit toplayabilme becerim... & & 0,640 & & & & & & \\
\hline İcra ve İflas hukuku bilgim... & & & 0,730 & & & & & \\
\hline Borçlar hukuku bilgim... & & & 0,727 & & & & & \\
\hline Medeni hukuk bilgim... & & & 0,713 & & & & & \\
\hline Tüketicinin Korunması Hakkında Kanun ile ilgili bilgim & & & 0,712 & & & & & \\
\hline Ticaret hukuku bilgim... & & & 0,608 & & & & & \\
\hline Sermaye piyasası mevzuatı bilgim... & & & 0,547 & & & & & \\
\hline Muhasebe standartları bilgim... & & & 0,506 & & & & & \\
\hline Tarafsız davranabilme özelliğim... & & & & 0,818 & & & & \\
\hline Dürüst davranabilme özelliğim... & & & & 0,813 & & & & \\
\hline Mesleki sırları saklayabilme özelliğim... & & & & 0,752 & & & & \\
\hline Mesleki dikkat ve özen gösterebilme özelliğim... & & & & 0,661 & & & & \\
\hline Bağımsız davranabilme özelliğim... & & & & 0,653 & & & & \\
\hline Haksız rekabete karşı duyarlılığım... & & & & 0,596 & & & & \\
\hline Mali analiz bilgim... & & & & & 0,724 & & & \\
\hline İnşaat muhasebesi bilgim... & & & & & 0,721 & & & \\
\hline Vergi mevzuatı uygulama bilgim... & & & & & 0,714 & & & \\
\hline Maliyet muhasebesi bilgim... & & & & & 0,673 & & & \\
\hline Genel muhasebe bilgim... & & & & & 0,651 & & & \\
\hline Sözel iletişim yeteneğim... & & & & & & 0,774 & & \\
\hline Empati yapma yeteneğim... & & & & & & 0,706 & & \\
\hline Yazılı iletişim yeteneğim... & & & & & & 0,689 & & \\
\hline $\begin{array}{l}\text { Mesleki konuları anlaşılır bir şekilde ifade edebilme } \\
\text { yeteneğim }\end{array}$ & & & & & & 0,668 & & \\
\hline Detaylara dikkat etme özelliğim... & & & & & & & 0,669 & \\
\hline Analitik (çözümleyici) düşünme özelliğim... & & & & & & & 0,630 & \\
\hline Olaylara karşı sezgisel yaklaşma özelliğim... & & & & & & & & 0,696 \\
\hline Olaylara karşı şüpheyle yaklaşma özelliğim... & & & & & & & & 0,617 \\
\hline
\end{tabular}

Tablo 2'de değişkenlerin hangi faktör altında yer aldığı görülmektedir. Bu tabloda orijinal değişken ve onun faktörü arasındaki korelasyon değerleri yer almaktadır. Buna göre faktör analizi sonucunda tespit edilen 8 faktör, aşağıdaki gibi adlandırılmıştır.

1. Faktör: Denetim Bilgi Düzeyi Faktörü, 
2. Faktör: Soruşturma Bilgi Düzeyi Faktörü,

3. Faktör: Hukuki Bilgi Düzeyi Faktörü,

4. Faktör: Ahlaki Değerler Faktörü,

5. Faktör: Mesleki Bilgi Düzeyi Faktörü,

6. Faktör: Yetenek Düzeyi Faktörü,

7. Faktör: Analitik Düşünce Faktörü,

\section{Faktör: Önsezi Faktörü}

Faktör analizi sonucunda belirlenen temel özelliklerin Bozkurt'un 2000 yılında yaptığ1 çalışmada belirttiği özelliklerle benzeştiği görülmektedir. Bozkurt 2000 yılında yaptığı çalışmada, adli muhasebecide bulunması gereken özellikleri, hukuk, denetim, muhasebe, soruşturma bilimleri, ahlaki nitelikler ve kişisel nitelikler şeklinde sıralamıştır. Bu açıdan bakıldığında, faktör analizi sonucu belirlenen faktörlerin literatüre uygun olduğu bu nedenle araştırmanın geçerliliğinin oldukça yüksek olduğu söylenebilir.

\subsection{Muhasebe Meslek Mensuplarına Yönelik Araştırma Bulguları}

Ankete katılan meslek mensuplarının demografik özellikleri şöyle özetlenebilir. Araştırma kapsamında 495 muhasebe meslek mensubuna ulaşılmıştır. Katılımcıların \%77.8'i erkek; \%22.2'si ise kadındır. Katılımcıların büyük çoğunluğunu \%39'luk oranla 31-40 yaş aralığındaki katılımcılar oluştururken, araştırmaya katılanlardan 51 ve üzeri yaş grubu \% 10.7’lik oranla araştırmaya katılan yaş gruplarından en küçük çoğunluğu oluşturan grup olmuştur. Bunun nedeni araştırma kapsamında anketlerin büyük çoğunluğunun internet anketi şeklinde cevaplanmış olması ve bu yaş grubu arasında internet kullanımının çok yaygın olmaması olduğu söylenebilir. Katılımcıların büyük çoğunluğunu \%86.7'lık oranla SMMM'ler oluşturmaktadır. Araştırmaya katılanların büyük çoğunluğunu \%52,52'lik oranla 1-10 y1l aralığında faaliyet gösteren katılımcılar oluştururken en az çoğunluğu \%5,3’lük oranla 31 ve üzeri yıl aralığında faaliyet gösteren katılımcılar oluşturmaktadır. Meslekteki çalışma süresi arttıkça katılım oranı azalmıştır. Bunun nedeni; anketlerin büyük çoğunluğunun internet anketi şeklinde cevaplanmış olması ve meslekteki çalışma süresi arttıkça yaş ortalamasının da artması, yaş ilerledikçe internet kullanımının azalması olarak açıklanabilir. Araştırmaya katılanların en büyük çoğunluğunu \% 75,6'lık oranla lisans mezunları oluşturmaktadır. Katılımcıların faaliyette bulundukları bölgelere göre dağılımında ilk üç bölge sıralaması \%35,6's1 Marmara Bölgesi, \% 34,7'si İç Anadolu Bölgesi, \% 21,8'i Karadeniz Bölgesi şeklindedir. Doğu Anadolu Bölgesinden araştırmaya katılım olmamıştır. Katılımcıların \% 22,2'si, bilirkişilik yaptığını belirtirken \% 77,8'i, bilirkişilik yapmadığını belirtmiştir. Katılımcıların büyük bir çoğunluğu bilirkişilik yapmamıştır. Katılımcıların; \% 71,9'u, bilirkişilik yapmak istediğini belirtirken \% 28,1'i, bilirkişilik yapmak istememektedir. Katılımcıların büyük bir çoğunluğu bilirkişilik yapmak istemektedir. Araştırmaya katılanların \% 
88,3' ü, muhasebe meslek mensuplarının uzman tanıklık yapmaları için eğitim almalarının gerekli olduğunu belirtirken; \% 11,7'si, eğitim almalarının gerekli olmadığını belirtmiştir. Araştırmaya katılanların \% 69,7'si, bu konuda eğitim almak isterken; \% 30,3'ü, bilirkişilik eğitimi almak istemediğini belirtmiştir. Katılımcıların büyük bir çoğunluğu bilirkişilik eğitimi almak istediklerini belirtmiştir. Ancak muhasebe meslek mensuplarının bilirkişilik yapmak için eğitim almalarının gerekli olduğunu belirten katılımcıların, kendilerinin eğitim alması konusunda bu kadar da istekli olmadıkları görülmektedir.

Muhasebe meslek mensuplarının uzman tanıklık yeterliliklerini ölçmeyi amaçlayan ve faktör analizi ile sekiz faktör altında gruplandırılan soruların tanımlayıcı istatistikleri Tablo 3'de gösterilmiştir. Tablo 3'de yer alan faktörlerin ortalamaları incelenerek muhasebe meslek mensuplarının uzman tanıklık yeterlilikleri hakkında fikir elde etmek mümkündür. Tablo 3 yorumlanırken, beşli ölçek "1- Çok Kötü, 2-Kötü, 3-Orta, 4-İyi, 5- Çok İyi” dikkate alınmıştır. Sonuçlar, dördün üzerindeki ortalama yeterli, dördün altındaki ortalama yetersiz olacak şeklinde yorumlanmıştır. Bir başka ifade ile, dördün üzerinde ortalamaya sahip faktörler açısından, muhasebe meslek mensuplarının yeterli olduğu söylenecektir.

Tablo 3. Faktörlerin Tanımlayıcı İstatistikleri

\begin{tabular}{|l|c|}
\hline \multicolumn{1}{|c|}{ Faktör İsmi } & Ortalama \\
\hline Denetim Bilgi Düzeyi Faktörü & $\mathbf{3 , 9 8 9 9}$ \\
\hline Soruşturma Bilgi Düzeyi Faktörü & $\mathbf{3 , 3 3 2 3}$ \\
\hline Hukuki Bilgi Düzeyi Faktörü & $\mathbf{3 , 4 8 6 9}$ \\
\hline Ahlaki Değerler Faktörü & $\mathbf{4 , 6 7 0 4}$ \\
\hline Mesleki Bilgi Düzeyi Faktörü & $\mathbf{4 , 0 5 6 6}$ \\
\hline Yetenek Bilgi Düzeyi Faktörü & $\mathbf{4 , 2 8 7 4}$ \\
\hline Analitik Düşünce Faktörü & $\mathbf{4 , 3 6 2 7}$ \\
\hline Önsezi Faktörü & $\mathbf{4 , 0 8 2 8}$ \\
\hline
\end{tabular}

Tablo 3'deki veriler genel olarak değerlendirildiğinde; muhasebe meslek mensuplarının uzman tanıklık yeterliliklerini ölçülmeyi amaçlayan faktör gruplarının ortalamalarının iyi ve orta seviyelerde olduğu görülmektedir. Bir meslek uygulayıcısının mesleki anlamda yeterli olduğunu söylemek için kişinin en azından iyi seviyenin üzerinde yeterliliğe sahip olması gerekmektedir. Faktör ortalamalarından sadece ahlaki değerler, mesleki bilgi düzeyi, yetenek bilgi düzeyi, analitik düşünce ve önsezi faktörlerinin ortalama değerleri iyi seviyenin üzerinde çıkmaktadır. Bu sebeple sayılan faktörler için muhasebe meslek mensuplarının gerekli yeterliliğe sahip olduklarını düşündükleri söylenebilecekken diğer faktörler olan denetim bilgi düzeyi, hukuki bilgi düzeyi ve soruşturma bilgi düzeyi için muhasebe meslek mensuplarının gerekli yeterliliğe sahip olduklarını düşünmedikleri söylenebilir. 


\subsection{Adalet Uygulayıcılarına (Hakimler) Yönelik Araştırma Bulguları}

Araştırma kapsamında 60 hakime ulaşılmıştır. Katılımcıların sorulara verdikleri cevaplar Tablo 4'de özetlenmiştir.

Tablo 4. Katılımcıların Verdikleri Cevaplar (n:60)

\begin{tabular}{|l|c|c|}
\hline & Evet \% & Hayır \% \\
\hline Bilirkissilik Sistemi Günümüz Yargısı için Yeterli mi? & 14,3 & 85,7 \\
\hline Uzman Tanıklı̆a Gerek Var mı? & 88,6 & 11,4 \\
\hline Muhasebe Meslek Mensupları Uzman Tanıklık Yapabilir mi? & 88,6 & 11,4 \\
\hline
\end{tabular}

Tablo 4'e göre katılımcıların \%85.7'si bilirkişilik sisteminin günümüz yargısı için yetersiz olduğunu belirtirken \%14.3'ü bilirkişilik sisteminin günümüz yargısı için yeterli olduğunu belirtmektedir. Katılımcıların \%88.6'sı uzman tanıklık sistemine ihtiyaç duyulduğunu belirtirken \%11.4'ü uzman tanıklığa gerek olmadığını belirtmiştir. Yine katılımcıların \%88.6'sı muhasebe meslek mensuplarının uzman tanıklık yapabileceğini belirtirken \%11.4'ü muhasebe meslek mensuplarının uzman tanıklık yapamayacağını belirtmiş̧ir.

Bu durumda, adalet uygulayıcılarının, bilirkişilik müessesesinden memnun olmadıkları, yeni bir sisteme ihtiyaç duyulduğu, bu anlamda uzman tanıklık mesleğinin sorunlara çare olabileceği, bu mesleğe en yatkın kişilerin muhasebe meslek elemanları olduğu yönünde genel bir eğilimin olduğu söylenebilir.

Muhasebe meslek mensupları üzerinde yapılan araştırmada, meslek mensuplarının uzman tanıklığın gerektirdiği 5 özellik açısından yeterli olduklarını düşündükleri belirlenmişti. Burada, aynı sorular adalet uygulayıcısı hakimlere sorularak, hakimlerin aynı konuda meslek mensupları için ne düşündükleri ortaya konmaya çalışılmıştır. Adalet uygulayıcısı olan hakimlerin, muhasebe meslek mensuplarının uzman tanıklık mesleğini yerine getirip getiremeyeceklerine yönelik düşünceleri Tablo 5'de özetlenmiştir.

Tablo 5'de, hakimlerin muhasebe meslek mensuplarının uzman tanıklık yeterlilikleri konusundaki algıları 5 li ölçek üzerinden değerlendirilmiş puanları yer almaktadır. Buna göre, hakimlerin tüm faktörler açısından muhasebe meslek mensuplarına 5 üzerinden 3 civarında bir yeterlilik puanı verdikleri gözlemlenmiştir. En yüksek puanın ise ahlaki değerler ve mesleki bilgi düzeyine yönelik algıda ortaya çıktığı görülmektedir.

Tablo 5. Faktörlerin Tanımlayıcı İstatistikler

\begin{tabular}{|l|c|}
\hline \multicolumn{1}{|c|}{ Faktör İsmi } & Ortalama \\
\hline Denetim Bilgi Düzeyi Faktörü & $\mathbf{3 , 3 4 2 9}$ \\
\hline Soruşturma Bilgi Düzeyi Faktörü & $\mathbf{3 , 1 1 4 3}$ \\
\hline Hukuki Bilgi Düzeyi Faktörü & $\mathbf{3 , 3 0 2 1}$ \\
\hline & $\mathbf{3 , 5 7 1 4}$ \\
\hline Ahlaki Değerler Faktörü & $\mathbf{3 , 5 6 5 7}$ \\
\hline Mesleki Bilgi Düzeyi Faktörü & \\
\hline
\end{tabular}




\begin{tabular}{|l|c|}
\hline \multicolumn{1}{|c|}{ Faktör İsmi } & Ortalama \\
\hline Yetenek Bilgi Düzeyi Faktörü & $\mathbf{3 , 4 0 7 2}$ \\
\hline Kişisel Özellikler Faktörü & $\mathbf{3 , 4 7 1 5}$ \\
\hline Önsezi Faktörü & $\mathbf{3 , 4 4 2 9}$ \\
\hline
\end{tabular}

$\mathrm{Bu}$ sonuçlara göre, dördün altındaki puanın yetersiz kabul edileceği yargısı dikkate alındığında, hakimlerin tüm faktörler açısından muhasebe meslek mensuplarının yetersiz olduklarını düşündüklerini söylemek mümkündür. $\mathrm{Bu}$ durum, muhasebe meslek camiasının üzerinde durmas1 gereken önemli bir ayrıntıdır. Hakimlerin, en düşük puan verdikleri özellik, soruşturma, hukuki ve denetim bilgi düzeyleridir. Buna göre, ortalama değerlerin 4'ün altında 3’ün üstünde olmas1 hakimlerin meslek mensuplarının bu işi yapabileceklerini ancak tam anlamı ile yeterli olmadıklarını düşündükleri şeklinde yorumlanabilir. Bu sonuç, zaten beklenen bir durumdur. Çünkü, bir çok araştırmada bu yönlü sonuçlar ortaya çıktığı görülmektedir.

\subsection{Muhasebe Meslek Mensupları ile Hakimlerin Yargılarının Karşılaştırılması}

Uzman tanıkta bulunması gereken özelliklerin mevcut muhasebe meslek mensuplarında bulunup bulunmadığı sorusuna, meslek mensupları ile hakimlerin verdiği cevaplar Tablo 6'da karşılaştırılmıştır.

Tablo 6. Sonuçların Karşılaştırılması

\begin{tabular}{|l|c|c|}
\hline \multicolumn{1}{|c|}{ Faktör İsmi } & $\begin{array}{c}\text { Muhasebe Meslek } \\
\text { Mensupları }\end{array}$ & Hakimler \\
\hline Denetim Bilgi Düzeyi Faktörü & 3,9899 & 3,3429 \\
\hline Soruşturma Bilgi Düzeyi Faktörü & 3,3323 & 3,1143 \\
\hline Hukuki Bilgi Düzeyi Faktörü & 3,4869 & 3,3021 \\
\hline Ahlaki Değerler Faktörü & 4,6704 & 3,5714 \\
\hline Mesleki Bilgi Düzeyi Faktörü & 4,0566 & 3,5657 \\
\hline Yetenek Bilgi Düzeyi Faktörü & 4,2874 & 3,4072 \\
\hline Analitik Düşünce Faktörü & 4,3627 & 3,4715 \\
\hline Önsezi Faktörü & 4,0828 & 3,4429 \\
\hline
\end{tabular}

Tablo 6 karşılaştırıldığında, tüm faktörler açısından hakimlerin düşüncelerinin, meslek mensuplarına göre daha olumsuz olduğu görülmektedir. Bu durum, muhasebe meslek camiasının üzerinde durması ve "niçin hakimler daha olumsuz?" sorusuna cevap vermesi gereken ayrıntılardan birini oluşturmaktadır.

\section{SONUÇ}

Yapılan araştırmalar ülkemiz bilirkişilik uygulamasının günümüz yargısı için yeterli olmadığını ve ülkemizde de sertifikalı bilirkişi olarak görev yapacak uzman tanıklara ihtiyaç duyulduğunu göstermektedir. Ancak ülkemiz muhasebe meslek mensuplarının şu an için gerekli uzman tanıklık yeterliliğine sahip olduğunu söylemek mümkün değildir. Bu çalışmanın sonucu da bu yargıyı destekler niteliktedir. Çalışma sonucuna göre, meslek mensuplarının uzman tanıklık yeterliliği orta düzeyde 
çıkmaktadır. Hakimler ile Meslek mensupları arasında ise konuya bakış açılarında farklılıklar ortaya çıkmaktadır. Hakimler, meslek mensuplarına göre konuya daha olumsuz yaklaşmaktadırlar.

Meslek mensuplarının kendilerini değerlendirirken, tarafsız olamayacakları gözönüne alınacak olursa, tarafsız bakış açılarıyla hakimlerin görüşlerinin bu konuda çok daha değerli olduğu söylenebilir. $\mathrm{Bu}$ nedenle, araştırma sonucunun hakimlerin görüşü üzerine oturtulması daha doğru olacaktır. Buna göre, muhasebe meslek mensuplarının uzman tanıklık mesleği açısından yeterli olmadıkları, bu konuda mutlaka eğitimden geçirilmeleri gerektiğini söylemek mümkündür.

Uzman tanıklık mesleğinin, ülkemizde uygulanması için öncelikle eğitim faaliyetlerine ağırlık verilmeli ve eğitimlerde başarılı olanlara uzman tanıklık sertifikası verilmelidir. Uzman tanıklık sertifikasyon programlarının Üniversitelerde Sürekli Eğitim Merkezleri aracılığılla yapılmasının daha faydalı olacağı söylenebilir.

Adli muhasebecilerin eğitimi ve sertifikalandırılması aşamasında yurtdışındaki uygulamalara bakıldığında köklü kurumların bu işi üstlendiği ve alanlarında kaliteli hizmet verdiği görülmektedir. Ülkemizdeki uygulamaya bakıldığında ise İSMMMO Akademi tarafından 2 Ekim 2010 tarihinden itibaren "Bağımsız Adli Muhasebe Uzmanlığı Programı" adı altında adli muhasebe eğitimi verildiği ve bu eğitimi başarıyla tamamlayanlara bir katılımcı sertifikası verildiği görülmektedir (ISMMMO Akademi (2011), Bağımsız Adli Muhasebe Uzmanlığı Programı). Ancak dünyadaki diğer örnekleri ile karşılaştırıldığında bu sertifikanın genel geçer düzeyde olduğu ve eğitimin yeterli olduğunu söylemek mümkün değildir.

Adli muhasebecilere uygulanacak eğitiminin kalitesinin oldukça yüksek ve çağın gereklerine ayak uydurabilecek seviyede olması gerekmektedir. Bu anlamda adli muhasebe eğitiminin muhasebe, hukuk, denetim, soruşturma ve suç bilimi konularını kapsaması gerekmektedir. Ayrıca bu eğitimler staj benzeri uygulamaya yönelik çalışmalarla desteklenmelidir.

Adli muhasebecilik mesleğinde kurumsallaştırmaya gidilip meslek uygulayıcılarının sertifikalandırılmasından sonra bilirkişilik kurumunda yaşanan sorunların çözümü amacıyla adli muhasebeci ve uzman tanık olarak sertifika alanların bilirkişi olarak görev yapması gerekli yasal düzenlemelerle sağlanmalıdır. Bu aşamada ayrıca bilirkişilik yapmak isteyen adli muhasebeci ve uzman tanık sertifikası sahibi kişileri bir çatı altında toplayacak bir kurum oluşturulmalıdır. Bu kurum bilirkişilerin eğitiminden, ücretlendirilmesinden ve mahkemelerde görevlendirilmesinden sorumlu olmalıdır. Böylelikle bilirkişilik sisteminde sıklıkla dile getirilen sorunların çözümü sağlanacaktır.

\section{KAYNAKÇA}

Aktaş, H. ve Kuloğlu, G. (2008), “Adli Muhasebe ve Adli Muhasebecilik Mesleği”, Muhasebe ve Denetime Bakış Dergisi, Mayıs 2008, 101-120. 
Akyel, N. (2009), “Adli Muhasebecilik ve Türkiye'de Uygulanabilmesi için Altyapı Bileşenlerinin Mevcut Durumu, Değerlendirilmesi ve Öneriler”, Yayımlanmamış Doktora Tezi, Sakarya Üniversitesi Sosyal Bilimler Enstitüsü.

Alperen, S. A. ve Demirtaş, İ.(2010), “İnceleme Raporu”, http://www.icdenetim.adalet. gov.tr/faaliyet/yayinlanan_rapor/2010-4.pdf, 1-44.(11.01.2013).

Altunışık, R.,Coşkun, R., Bayraktaroğlu, S. ve Yıldırım, E. (2007), Sosyal Bilimlerde Araştırma Yöntemleri SPSS Uygulamal1, 5. Baskı, Sakarya: Sakarya Yayıncılık.

Bakırcı, A. E.(2003), "Türk Adli Sisteminde Bilirkişilik Uygulamaları, Sorunları ile Yakın ve Uzak Dönem için Çözüm Önerileri”, http://www.turkhukuksitesi. com/makale_115.htm (12.11.2010).

Bozkurt, N.(2000), "Muhasebe ve Denetim Mesleğinde Yeni Bir Alan 'Adli Muhasebecilik", Yaklaşım Dergisi, 8(94), 56-62, http://forum.alomaliye.com /index.php?topic=29886.0 (18.11.2010).

Crumbley, D.L. (1995), "Forensic Accountants Appearing in the Literatüre", New Accountant, 10(7),23-25, http://www.bus.lsu.edu/accounting/faculty/lcrumbley/forensic. html(12/11/ 2010).

Çabuk, A. ve Yücel, E. (2012), “Adli Muhasebecilik Mesleği ve Türkiye'de Uygulanabilirliğine Yönelik Bir Araştırma”, Muhasebe ve Finansman Dergisi, Nisan 2012, 27-50.

Çankaya, F. ve Gerekan, B. (2009), "Hile Denetçiliği Mesleği ve Sertifikalı Hile Denetçiliği Mesleki Standartları ve Ahlak Kuralları”, Muhasebe ve Denetime Bakış, Nisan2009, 93-108.

Çelikli, İ. (2006a), "Bilirkişiliğin Gerekliliği” http://www.muhasebetr.com/yazarlarimiz /İbrahim /001/ (12.11.2010).

Çelikli, İ. (2006b), “Bilirkişiliğin Gerekliliği-4” http://www.muhasebetr.com/yazarlarimiz /ibrahim/004/ (12.11.2010).

Çınar, S. (2009), “Türk Vergi Hukuku'nda Bilirkişilik Kurumu ve Analizi”, Yayınlanmamış Yüksek Lisans Tezi, Gazi Üniversitesi Sosyal Bilimler Enstitüsü.

Çoban, Y. (2013), “Adli Muhasebede Uzman Tanıklık Mesleği: Muhasebe Meslek Mensupları Üzerine Bir Araştırma ”, Yayımlanmamış Yüksek Lisans Tezi, Karadeniz Teknik Üniversitesi Sosyal Bilimler Enstitüsü.

Davis, C., Farell, R. ve Ogilby, S. (2009), “Characteristics and Skills of the Forensic Accountant”, 1-4, http://www.aicpa.org/InterestAreas/ForensicAndValuation/Resources/ PractAidsGuidance/ DownloadableDocuments/ForensicAccountingResearchWhitePaper.pdf (25.11.2010).

Emir, M. (2008) “Hile Denetimi”, Mali Çözüm Dergisi, (86), 109-121. 
Squar M. R.(2009), “Hire an Expert Witness?”(December 2009), Smart Business Orange County,2828.http://ehis.ebscohost.com/eds/results?sid=86c35a99-ae0b-478b-a8cb-5d0ce252 aad7\% 40sessionmgr4003\&vid=4\&hid=4110\&bquery $=\% 22 \mathrm{hire}+\mathrm{AND}+$ expert\%22+AND+Sm art+AND+Business+AND+Orange+AND+County\&bdata=Jmxhbmc9dHImdHlwZT0wJnNpd GU9ZWRzLWxpdmU\%3d (19.12.2013)

Hoffman, R. (2002) "Preparing for Expert Testimony", The Appraisal Journal, October 2002, 380386.

İstanbul Serbest Muhasebeci Mali Müşavirler Odası Akademi (2011), "Bağımsız Adli Muhasebe Uzmanlığ1 Programı", http://www.ismmmoakademi.com.tr/docs/brosurler /Ekim2011/ AdliMuhasebe.pdf (04.01.2013).

Karacan, S.(2012), "Hukuk ile Muhasebenin Kesişme Noktası: Adli Muhasebe”, Uluslararasi İktisadi ve İdari İncelemeler Dergisi, 4(8), 105-128.

Kaya, U. (2005), "Muhasebe Mesleğinde Adli Muhasebe Uzmanlığı ve Türkiye Açısından Gerekliliği”, Muhasebe ve Bilim Dünyası Dergisi, 7(1), 49-64.

Kumkale, R.(2005), "Bilirkişilik ve Mali Müşavirlik Mesleği”, http://www.F2.7.alomaliye .com/ruknettin_kumkale_bilirkisilik.htm (11.11.2010).

Kurt, G. ve Uçma, T. (2009), “Adli Muhasebecilik Mesleği ve Adli Muhasebeci Olabilme Sürecinin Türkiye'deki ve Amerika'daki Yasal Düzenlemeler Açısından Karşılaştırılması” Ticaret ve Turizm Eğitim Fakültesi Dergisi, 2009(2), 160-178.

Larosa, L. A. (2009), “A Practical Approach to Expert Witness Testimony”, http://www.picpa.org /Content/40016.aspx (25.11.2010).

Mc Daniel, C. ve Gates, R. (1996), “Contemporary Marketing Research”, San Francisco.

Murray, S. L. (2009) “ Being an Expert Witness”, Professional Safety, March 2009, 20-23.

Özkul, F. U. ve Pektekin, P. (2009), "Muhasebe Yolsuzluklarının Tespitinde Adli Muhasebecinin Rolü ve Veri Madenciliği Tekniklerinin Kullanılması”, MÖDAV, 4, 57-88.

Pazarçeviren, Y. (2005) “Adli Muhasebecilik Mesleği”, ZKÜ Sosyal Bilimler Dergisi,1(2),1-19.

Pehlivan, A. ve Dursun A.(2012), “Türkiye'de Adli Muhasebe Eğitimine Yönelik Bir Araştırma”, Atatürk Üniversitesi İktisadi ve İdari Bilimler Dergisi, 26(2), 129-141

Seviğ, V. (2002), "Bilirkişilik", http://www.malihaber.com/modules.php?name =Encyclopedia\& $\mathrm{op}=$ content $\&$ tid $=28812(10 / 12 / 2010)$. 
Şahin, B. (2011), “Adli Muhasebecilik Mesleği ve 6120 Sayılı Türk Ticaret Kanunu Açısından İncelenmesi”, Yayımlanmamış Yüksek Lisans Tezi, Marmara Üniversitesi Sosyal Bilimler Enstitüsü.

Toraman, C, Abdioğlu, H. ve İşgüden, B.(2009) “Aklama Suçunun Önlenmesine Yönelik Çabalar: Adli Muhasebecilik Mesleği ve Uygulamaları", Afyon Kocatepe Üniversitesi, İ.İ.B.F. Dergisi, $10(1), 17-54$.

Türkiye Serbest Muhasebeci Mali Müşavirler ve Yeminli Mali Müşavirler Odaları Birliği (2012a), "Meslek Mensubu Dağılım Tablosu SM ve SMMM" http://www.turmob. org.tr/TurmobWeb/Attachment.aspx?param=TDLPfWtFdrm1e8Dlv7FNOoH6uk4KIkiU9mR FMeskCPG6O606XtOBzMOW0SM81//gowKqVpD7XHUTiz1lrjY74w== (05.10.2012).

Türkiye Serbest Muhasebeci Mali Müşavirler ve Yeminli Mali Müşavirler Odaları Birliği (2012b), "Meslek Mensubu Dağılım Tablosu YMM", http://www.turmob. Org.tr/TurmobWeb/Attachment.aspx?param=jGL4YtEdKTuh2azZ6BNhZB75PuC0S6SsUyn WTVBEh7YA/+GNJiBOOgjF3eEt1CkTtP6Be6VA7dJvTBwSKx8Gmw== (05.10.2012)

URL, “Biz Kimiz”, (2011), http://www.frcdenetim.com/index.php/tr/hakkimizda/5/biz-kimiz (04.01. 2012).

Usul, H. ve Topçuoğlu, M. (2011), "Finansal Manipülasyonların Ortaya Çıkarılması ve Önlenmesinde Adli Muhasebenin Önemi: Türk Hukuk Sisteminde Var Olması Gerekliliği Üzerine Bir Tartışma”, Süleyman Demirel Üniversitesi İktisadi ve İdari Bilimler Fakültesi Dergisi, 16(3), 53-66. 


\section{EKLER}

\section{EK-1:MUHASEBE MESLEK MENSUPLARINA UYGULANAN ANKET FORMU}

\section{ADLİ MUHASEBECILIIKTE UZMAN TANIKLIK MESLEĞİ AÇISINDAN MUHASEBE MESLEK ELEMANLARININ DURUMLARININ INCELENMESİ ANKETI}

1.Cinsiyetiniz?
( ) Bay
2.Yaşınız?

( ) Bayan

( ) $18-30$

( ) $31-40$

( ) $41-50$

( ) 51 ve üzeri

3.Mesleki unvanını?
( ) YMM
( ) SMMM
( )SM

4.Meslekte kaçıncı yılınız?
( ) 1-10
( ) $11-20$
( )21-30
( ) 31ve üzeri

5.Eğitim durumunuz?
( )Lise
( )Ön Lisans
( )Lisans
( )Yüksek Lisans
( )Doktora

6.Faaliyette bulunduğunuz bölge?
( ) Karadeniz
( )Doğu Anadolu
( )Güney Doğu Anadolu
( ) İç Anadolu
( ) Marmara
( )Ege
( )Akdeniz

7.Bilirkişilik yaptınız mı?
( ) Evet
( ) Hayır

8.Bilirkişilik yapmak ister misiniz?
( ) Evet
( ) Hayır

9.Muhasebe meslek mensuplarının bilirkişilik yapmak için eğitim almaları gerekli midir?
( ) Evet
( ) Hayır

10.Bilirkişilik eğitimi almak ister misiniz?
( ) Evet
( ) Hayır

\begin{tabular}{|c|c|c|c|c|c|}
\hline $\begin{array}{c}\text { Uzman Tanıklık Açısından Aşağıda Sıralanan Kişisel } \\
\text { Özelliklerle İlgili İfadeleri Kendi Açınızdan } \\
\text { Değerlendiriniz. }\end{array}$ & $\begin{array}{c}(5) \\
\text { Çok iyi }\end{array}$ & $\begin{array}{l}(4) \\
\text { İyi }\end{array}$ & $\begin{array}{l}(3) \\
\text { Orta }\end{array}$ & $\begin{array}{c}(2) \\
\text { Kötü }\end{array}$ & $\begin{array}{l}\text { (1) } \\
\text { Çok } \\
\text { kötü }\end{array}$ \\
\hline \multicolumn{6}{|l|}{ 1.Analitik (çözümleyici) düşünme özelliğim... } \\
\hline \multicolumn{6}{|l|}{ 2.Detaylara dikkat etme özelliğim... } \\
\hline \multicolumn{6}{|l|}{ 3.Hoşgörülü davranma özelliğim... } \\
\hline \multicolumn{6}{|l|}{ 4.Meraklı davranma özelliğim... } \\
\hline \multicolumn{6}{|l|}{ 5.Olaylara karşı sezgisel yaklaşma özelliğim... } \\
\hline \multicolumn{6}{|l|}{ 6.Israrcı davranma özelliğim... } \\
\hline \multicolumn{6}{|l|}{ 7.Olaylara karşı şüpheyle yaklaşma özelliğim... } \\
\hline \multicolumn{6}{|l|}{ 8.Baskı altında karar verebilme özelliğim... } \\
\hline \multicolumn{6}{|l|}{ 9.Öz güvenim... } \\
\hline \multicolumn{6}{|l|}{ 10.Ekip çalışmasına uyum sağlayabilme özelliğim... } \\
\hline \multicolumn{6}{|l|}{ 11.Araştırmacı bir yaklaşım sergileme özelliğim... } \\
\hline $\begin{array}{c}\text { Uzman Tanıklık Açısından Aşağıda Sıralanan Ahlaki } \\
\text { Değerlerle İlgili İfadeleri Kendi Açınızdan } \\
\text { Değerlendiriniz. }\end{array}$ & $\begin{array}{c}(5) \\
\text { Çok iyi }\end{array}$ & $\begin{array}{l}\text { (4) } \\
\text { İyi }\end{array}$ & $\begin{array}{l}(3) \\
\text { Orta }\end{array}$ & $\begin{array}{c}(2) \\
\text { Kötü }\end{array}$ & $\begin{array}{l}\text { (1) } \\
\text { Çok } \\
\text { kötü }\end{array}$ \\
\hline \multicolumn{6}{|l|}{ 1.Bağımsız davranabilme özelliğim... } \\
\hline 2.Mesleki sırları saklayabilme özelliğim... & & & & & \\
\hline
\end{tabular}




\begin{tabular}{|c|c|c|c|c|c|}
\hline \multicolumn{6}{|l|}{ 3.Dürüst davranabilme özelliğim... } \\
\hline \multicolumn{6}{|l|}{ 4.Tarafsız davranabilme özelliğim... } \\
\hline \multicolumn{6}{|l|}{ 5.Haksız rekabete karşı duyarlılı̆̆ım... } \\
\hline \multicolumn{6}{|l|}{ 6.Mesleki dikkat ve özen gösterebilme özelliğim... } \\
\hline $\begin{array}{c}\text { Uzman Tanıklık Açısından Aşağıda Sıralanan Mesleki } \\
\text { Bilgi Düzeyiyle İlgili İfadeleri Kendi Açınızdan } \\
\text { Değerlendiriniz. }\end{array}$ & \begin{tabular}{c|c}
$(5)$ \\
Çok iyi
\end{tabular} & $\begin{array}{l}(4) \\
\text { İyi }\end{array}$ & $\begin{array}{l}(3) \\
\text { Orta }\end{array}$ & $\begin{array}{l}(2) \\
\text { Kötü }\end{array}$ & $\begin{array}{l}\text { (1) } \\
\text { Çok } \\
\text { kötü }\end{array}$ \\
\hline \multicolumn{6}{|l|}{ 1.Genel muhasebe bilgim... } \\
\hline \multicolumn{6}{|l|}{ 2.Maliyet muhasebesi bilgim... } \\
\hline \multicolumn{6}{|l|}{ 3.İnşaat muhasebesi bilgim... } \\
\hline \multicolumn{6}{|l|}{ 4.Mali analiz bilgim... } \\
\hline \multicolumn{6}{|l|}{ 5.Vergi mevzuat1 uygulama bilgim... } \\
\hline \multicolumn{6}{|l|}{ 6.Muhasebe standartları bilgim... } \\
\hline \multicolumn{6}{|l|}{ 7.Sermaye piyasası mevzuatı bilgim... } \\
\hline $\begin{array}{c}\text { Uzman Tanıklık Açısından Aşağıda Sıralanan Hukuki } \\
\text { Bilgi Düzeyiyle İlgili İfadeleri Kendi Açınızdan } \\
\text { Değerlendiriniz. }\end{array}$ & \begin{tabular}{c|c}
$(5)$ \\
Çok iyi
\end{tabular} & $\begin{array}{l}(4) \\
\text { İyi }\end{array}$ & $\begin{array}{l}(3) \\
\text { Orta }\end{array}$ & $\begin{array}{l}(2) \\
\text { Kötü }\end{array}$ & $\begin{array}{l}\text { (1) } \\
\text { Çok } \\
\text { kötü }\end{array}$ \\
\hline \multicolumn{6}{|l|}{ 1.Ticaret hukuku bilgim... } \\
\hline \multicolumn{6}{|l|}{ 2.Borçlar hukuku bilgim... } \\
\hline \multicolumn{6}{|l|}{ 3.Medeni hukuk bilgim... } \\
\hline \multicolumn{6}{|l|}{$\begin{array}{l}\text { 4.Tüketicinin Korunması Hakkında Kanun ile ilgili } \\
\text { bilgim... }\end{array}$} \\
\hline \multicolumn{6}{|l|}{ 5.İcra ve İflas hukuku bilgim... } \\
\hline \multicolumn{6}{|l|}{ 6.İş hukuku bilgim... } \\
\hline $\begin{array}{c}\text { Uzman Tanıklık Açısından Aşağıda Sıralanan } \\
\text { Soruşturma Bilgi Düzeyiyle İlgili İfadeleri Kendi } \\
\text { Açınızdan Değerlendiriniz. }\end{array}$ & $\begin{array}{c}(5) \\
\text { Çok iyi }\end{array}$ & $\begin{array}{l}(4) \\
\text { İyi }\end{array}$ & $\begin{array}{l}(3) \\
\text { Orta }\end{array}$ & $\begin{array}{l}(2) \\
\text { Kötü }\end{array}$ & $\begin{array}{l}\text { (1) } \\
\text { Çok } \\
\text { kötü }\end{array}$ \\
\hline \multicolumn{6}{|l|}{ 1.Suç bilimi (kriminoloji) bilgim... } \\
\hline \multicolumn{6}{|l|}{ 2.Psikoloji bilgim... } \\
\hline \multicolumn{6}{|l|}{ 3.Bilişim teknolojiler hakkındaki bilgim... } \\
\hline \multicolumn{6}{|l|}{ 4.Adli sürecin işleyişi hakkında bilgim... } \\
\hline \multicolumn{6}{|l|}{ 5.Soruşturma yürütebilme becerim... } \\
\hline \multicolumn{6}{|l|}{ 6.Kanit toplayabilme becerim... } \\
\hline $\begin{array}{c}\text { Uzman Tanıklık Açısından Aşağıgda Sıralanan } \\
\text { Denetim Bilgi Düzeyiyle İlgili İfadeleri Kendi } \\
\text { Açınızdan Değerlendiriniz. }\end{array}$ & $\begin{array}{c}(5) \\
\text { Çok iyi }\end{array}$ & $\begin{array}{l}(4) \\
\text { İyi }\end{array}$ & $\begin{array}{l}(3) \\
\text { Orta }\end{array}$ & $\begin{array}{l}(2) \\
\text { Kötü }\end{array}$ & $\begin{array}{l}\text { (1) } \\
\text { Çok } \\
\text { kötü }\end{array}$ \\
\hline 1.İç denetim bilgim... & & & & & \\
\hline 2. İç kontrol bilgim... & & & & & \\
\hline 3.Bağımsız (dış) denetim bilgim... & & & & & \\
\hline 4.Hile tespit etme yeteneğim... & & & & & \\
\hline 5.Kanıt toplama hakkında bilgim... & & & & & \\
\hline 6.Risk değerleme bilgim... & & & & & \\
\hline
\end{tabular}




\begin{tabular}{|l|c|c|c|c|c|}
\hline $\begin{array}{c}\text { Uzman Tanıklık Açısından Aşağıda Sıralanan Yetenek } \\
\text { Düzeyiyle İlgili İfadeleri Kendi Açınızdan } \\
\text { Değerlendiriniz. }\end{array}$ & $\begin{array}{c}\text { (5) } \\
\text { Çok iyi }\end{array}$ & $\begin{array}{c}\text { (4) } \\
\text { İyi }\end{array}$ & $\begin{array}{c}\text { (3) } \\
\text { Orta }\end{array}$ & $\begin{array}{c}\text { (2) } \\
\text { Kötü }\end{array}$ & $\begin{array}{c}\text { (1) } \\
\text { Cok } \\
\text { kötü }\end{array}$ \\
\hline 1.Yazılı iletişim yeteneğim... & & & & & \\
\hline 2.Sözel iletişim yeteneğim... & & & & & \\
\hline 3.Empati yapma yeteneğim... & & & & & \\
\hline 4.Mesleki konuları anlaşılır bir şekilde ifade edebilme & & & & & \\
\hline $\begin{array}{l}\text { 5.Her dava için özgün rapor hazırlayabilme yeteneğim... } \\
\text { 6.Araştırmalarımda Yargıtay ve Danıştay kararlarından } \\
\text { yararlanabilme becerim... }\end{array}$ & & & & & \\
\hline
\end{tabular}

\section{EK-2: HAKIMMLERE UYGULANAN ANKET FORMU}

\section{ADLİ MUHASEBEDE UZMAN TANIKLIK MESLEĞİ: MUHASEBE MESLEK MENSUPLARI ÜZERINE BİR ARAŞTIRMA ANKETİ}

1.Bilirkişilik sistemi günümüz yargısı için yeterli mi?

2.Bilirkişilik sisteminde yeni bir düzenleme yapılması gerekli midir?

3.Muhasebe meslek mensupları bilirkișilik yapabilir mi?

\begin{tabular}{|c|c|c|c|c|c|}
\hline $\begin{array}{l}\text { Aşağıda bilirkişilerin mesleki yeterliliklerini ve kişisel özelliklerini } \\
\text { sorgulayan ifadeleri değerlendiriniz }\end{array}$ & \begin{tabular}{|l|}
$(5)$ \\
Çok \\
iyi
\end{tabular} & $\begin{array}{l}\text { (4) } \\
\text { İyi }\end{array}$ & $\begin{array}{l}\text { (3) } \\
\text { Orta }\end{array}$ & $\begin{array}{l}\text { (2) } \\
\text { Kötü }\end{array}$ & \begin{tabular}{|l|}
$(1)$ \\
Çok \\
kötü
\end{tabular} \\
\hline \multicolumn{6}{|l|}{ Bilirkişilerin iç kontrol bilgisi... } \\
\hline \multicolumn{6}{|l|}{ Bilirkişilerin iç denetim bilgisi... } \\
\hline \multicolumn{6}{|l|}{ Bilirkişilerin bağımsız (dış) denetim bilgisi... } \\
\hline \multicolumn{6}{|l|}{ Bilirkişilerin hile tespit etme yeteneği... } \\
\hline \multicolumn{6}{|l|}{ Bilirkişilerin kanıt toplama hakkında bilgisi... } \\
\hline \multicolumn{6}{|l|}{ Bilirkişilerin risk değerleme bilgisi... } \\
\hline \multicolumn{6}{|l|}{ Bilirkişilerin soruşturma yürütebilme becerisi... } \\
\hline \multicolumn{6}{|l|}{ Bilirkişilerin psikoloji bilgisi... } \\
\hline \multicolumn{6}{|l|}{ Bilirkişilerin suç bilimi (kriminoloji) bilgisi... } \\
\hline \multicolumn{6}{|l|}{ Bilirkişilerin adli sürecin işleyişi hakkında bilgisi... } \\
\hline \multicolumn{6}{|l|}{ Bilirkişilerin bilişim teknolojiler hakkındaki bilgisi... } \\
\hline \multicolumn{6}{|l|}{ Bilirkişilerin kanıt toplayabilme becerisi... } \\
\hline \multicolumn{6}{|l|}{ Bilirkişilerin icra ve iflas hukuku bilgisi... } \\
\hline \multicolumn{6}{|l|}{ Bilirkişilerin borçlar hukuku bilgisi... } \\
\hline \multicolumn{6}{|l|}{ Bilirkişilerin medeni hukuk bilgisi... } \\
\hline \multicolumn{6}{|l|}{ Bilirkişilerin Tüketicinin Korunması Hakkında Kanun ile ilgili bilgisi... } \\
\hline \multicolumn{6}{|l|}{ Bilirkişilerin ticaret hukuku bilgisi... } \\
\hline \multicolumn{6}{|l|}{ Bilirkişilerin sermaye piyasası mevzuatı bilgisi... } \\
\hline \multicolumn{6}{|l|}{ Bilirkişilerin muhasebe standartları bilgisi... } \\
\hline \multicolumn{6}{|l|}{ Bilirkişilerin tarafsız davranabilme özelliği... } \\
\hline \multicolumn{6}{|l|}{ Bilirkişilerin dürüst davranabilme özelliği... } \\
\hline \multicolumn{6}{|l|}{ Bilirkişilerin mesleki sırları saklayabilme özelliğim... } \\
\hline \multicolumn{6}{|l|}{ Bilirkişilerin mesleki dikkat ve özen gösterebilme özelliği... } \\
\hline \multicolumn{6}{|l|}{ Bilirkişilerin bağımsız davranabilme özelliği... } \\
\hline Bilirkişilerin haksız rekabete karşı duyarlılığı... & & & & & \\
\hline
\end{tabular}
( ) Evet
( ) Hayır
( ) Evet
( ) Hayır
( ) Hayır

( ) Evet

\section{( ) Evet}




\begin{tabular}{|l|l|l|l|l|l|}
\hline $\begin{array}{l}\text { Aşağıda bilirkişilerin mesleki yeterliliklerini ve kişisel özelliklerini } \\
\text { sorgulayan ifadeleri değerlendiriniz }\end{array}$ & $\begin{array}{l}(5) \\
\text { Çok } \\
\text { iyi }\end{array}$ & $\begin{array}{l}(4) \\
\text { İyi }\end{array}$ & $\begin{array}{l}\text { (3) } \\
\text { Orta }\end{array}$ & $\begin{array}{l}\text { (2) } \\
\text { Kötü }\end{array}$ & $\begin{array}{l}\text { (1) } \\
\text { Çok } \\
\text { kötü }\end{array}$ \\
\hline Bilirkişilerin mali analiz bilgisi... & & & & & \\
\hline Bilirkişilerin inşaat muhasebesi bilgisi... & & & & & \\
\hline Bilirkişilerin vergi mevzuatı uygulama bilgisi... & & & & & \\
\hline Bilirkişilerin maliyet muhasebesi bilgisi... & & & & & \\
\hline Bilirkişilerin genel muhasebe bilgisi... & & & & & \\
\hline Bilirkişilerin sözel iletişim yeteneği... & & & & & \\
\hline Bilirkişilerin empati yapma yeteneği... & & & & \\
\hline Bilirkişilerin yazılı iletişim yeteneği... & & & & & \\
\hline Bilirkişilerin mesleki konuları anlaşılır bir şekilde ifade edebilme yeteneği... & & & & & \\
\hline Bilirkişilerin detaylara dikkat etme özelliği... & & & & & \\
\hline Bilirkişilerin analitik (çözümleyici) düşünme özelliği... & & & & \\
\hline Bilirkişilerin olaylara karş1 sezgisel yaklaşma özelliği... & & & & \\
\hline Bilirkişilerin olaylara karşı şüpheyle yaklaşma özelliği... & & & \\
\hline
\end{tabular}

